\title{
Effect of trellising system on grape and wine composition of Syrah vines grown in the cerrado region of Minas Gerais
}

\author{
Efeito do sistema de condução no perfil analítico das bagas e vinhos da cultivar Syrah \\ produzida na região do cerrado de Minas Gerais
}

\begin{abstract}
Renata Vieira da MOTA ${ }^{1 *}$, Daniel Angelucci de AMORIM ${ }^{1}$, Ana Carolina FAVERO², Eduardo PURGATTO³ Murillo de Albuquerque REGINA ${ }^{1}$
\end{abstract}

\begin{abstract}
Based on the concept that the trellising system affects not only sunlight interception and carbon assimilation, but also the fruitzone microclimate, which has a great impact on fruit composition and consequently on wine quality, the effect of two trellising systems - Vertical Shoot Position (VSP) and modified Geneva Double Curtain (GDC) - on wine and berry composition of Syrah grapes grown in João Pinheiro, Northeast region of Minas Gerais State, Brazil was investigated. The parameters such as $\mathrm{pH}$, berry size and weight, and seeds total phenolic contents were not affected by the training system. The GDC system produced fruits with the highest Brix and lowest titratable acidity. Berries from the VSP system presented lower anthocyanin concentration than those from the GDC system. Similar results were found for the total phenolic content of the skin of grape berries from the VSP system. GDC wines were characterized by high anthocyanin content and red color, resulting in wines with high color intensity. These data suggest that in the tropical region of Minas Gerais state, with high temperature and high sunlight intensity, the trellising system, which protects bunches against excessive radiation, should be chosen.
\end{abstract}

Keywords: Vitis vinifera; canopy management; composition; phenolic compounds.

\begin{abstract}
Resumo
Baseado no conceito de que o sistema de condução exerce influência não apenas na interceptação da luz solar e assimilação do carbono, mas também no microclima dos cachos com reflexos na maturação das uvas e qualidade do vinho, o efeito de dois sistemas de condução - espaldeira (VSP) e Dupla Cortina de Genevamodificado (GDC) - foi estudado na composição das bagas e do vinho da cultivar Syrah, produzida em João Pinheiro, noroeste de Minas Gerais, Brasil. As bagas apresentaram, na colheita, composição semelhante de pH, compostos fenólicos nas sementes, tamanho e peso da baga. O mosto das uvas conduzidas no sistema GDC apresentou maior teor de sólidos solúveis e menor acidez. Os teores de antocianinas nas cascas foram inferiores no sistema em espaldeira quando comparado ao GDC. Comportamento semelhante foi observado em relação aos fenólicos totais com valores inferiores no sistema espaldeira. Os vinhos elaborados a partir de uvas conduzidas em GDC apresentaram maiores teores de antocianinas e coloração vermelha, resultando na elaboração de vinhos com maior intensidade de cor. Os resultados indicam que, em regiões tropicais do Estado de Minas Gerais, com elevada incidência luminosa e altas temperaturas, deve-se optar por sistemas de condução que protejam os cachos contra o excesso de radiação.

Palavras-chave: Vitis vinifera; manejo do dossel; composição; compostos fenólicos.
\end{abstract}

\section{Introduction}

In recent years, many studies have been carried out to identify the potential of grape growing regions in order to produce quality wines based on the concept of terroir (GUERRA et al., 2006; REGINA et al., 2006; ROSIER, 2006). In the state of Minas Gerais, Brazil, the vineyards are located in two distinct regions: one in the South with Vitis labrusca varieties and the other in the Northern region with Vitis vinifera table grape varieties (PROTAS; CAMARGO; MELLO, 2006). The region of João Pinheiro is located in the Northeast part of the state (savanna) in a mesoclimate winegrowing region, but it has no viticultural tradition. However, a study by Tonietto, Vianello and Regina (2006) pointed out the region as a potential place to produce high quality wines from grapes harvested in dry season.
In hot climates such as that of the Minas Gerais Cerrado (savanna mesoclimate), it is well known that the direct incidence of sunlight into bunches affect grape sensory attributes due to excessive degradation of organic acids or aroma precursors causing negative effects on wine quality (TODA, 1991; SMART; ROBINSON, 1991). On the other hand, it is also known that canopy management by the use of different trellising systems affects not only the sunlight interception and carbon assimilation but also the fruitzone microclimate, which has a great impact on fruit composition and wine quality (CARBONNEAU, 1991; REYNOLDS; WARDLE; NAYLOR, 1996; REYNOLDS et al., 2004). The objective of this research was to compare some physicochemical characteristics of berries and wines of Syrah

${ }^{1}$ Núcleo Tecnológico EPAMIG Uva e Vinho, Av. Santa Cruz, 500, CP 33, CEP 37780-000, Caldas, MG, Brasil, e-mail: renata@epamigcaldas.gov.br

2 Departamento de Agricultura, Universidade Federal de Lavras - UFLA, CP 3037, CEP 37200-000, Lavras, MG, Brasil

${ }^{3}$ Faculdade de Ciências Farmacêuticas, Universidade de São Paulo - USP, Bloco 14, CP 66083, CEP 05315-970, São Paulo, SP, Brasil

* Corresponding author 
grapevines grown with two different training systems - Vertical Shoot Position (VSP) and modified Geneva Double Curtain (GDC) - in the Cerrado region of Minas Gerais State, Brazil.

\section{Materials and methods}

\subsection{Site location and plant material}

This study was conducted at a private vineyard in the municipality of João Pinheiro named Salvaterra II Farm. João Pinheiro coordinates are: $17^{\circ} 42^{\prime} \mathrm{S}, 46^{\circ} 10^{\prime} \mathrm{W}$, and $760 \mathrm{~m}$ height. The regional climate is classified as Aw - tropical wet with a dry season in the winter months. Annual sunlight corresponds to 2596 hours, mean relative humidity of $69.7 \%$, mean highest temperature of $28.8^{\circ} \mathrm{C}$, and mean daily thermal amplitude of $12.4{ }^{\circ} \mathrm{C}$ increasing up to $13{ }^{\circ} \mathrm{C}$ during the harvest month (TONIETTO; VIANELLO; REGINA, 2006). The vineyard orientated North-South in a soil composed mostly of sand.

The study was carried out in 2006 in a three-year-old Syrah vineyard (clone 470) grafted onto SO4 rootstock and irrigated by means of micro-spray. The vines were trained on two systems: Vertical Shoot Position (VSP) and modified Geneva Double Curtain (GDC). In the VSP system, vine spacing was $2.70 \times 1.50 \mathrm{~m}$, trained on a bilateral Royat Cordon at $1.0 \mathrm{~m}$ aboveground with shoots positioned upwards in three foliage wires (1.0 m of surface area) (Figure 1). In the GDC system, vine spacing was $3.0 \times 1.5 \mathrm{~m}$ with trunk height at $1.90 \mathrm{~m}$ aboveground with shoots horizontally divided and trained downwards. The curtains were supported at the top and the shoots were positioned to avoid an excessive light exposure on the fruit zone (Figure 2).

The pruning style was spur pruning with two nodes in length performed in March 2006 in lignified shoots formed during the growing season from September 2005 to March 2006. Each experimental block consisted of 1.0 ha vineyard with 2469 plants trained on the VSP and 2222 plants with the GDC training systems. VSP vines produced higher yield, $4.0 \mathrm{~kg}$ per vine, against $3.5 \mathrm{~kg}$ with GDC.

\subsection{Harvest and quality parameters}

The grape bunches were harvested in the morning and were immediately refrigerated at $5{ }^{\circ} \mathrm{C}$ and transported in refrigerated trucks to the Experimental Winery at Núcleo Tecnológico EPAMIG Uva e Vinho in the city of Caldas, Southern region of Minas Gerais, where a sample of 210 berries was randomly selected from the harvested bunches and used for physicochemical analyses.

The average berry weight was determined from a sample of 100 berries, and the average diameters (transversal and longitudinal) were determined from a sample of 50 berries with a Vernier caliper. After physical analysis, the berries were divided into three replicates of 70 berries. Each replicate was crushed in a polyethylene bag and filtered. The resulting juice was immediately analyzed for total soluble solids (TTS; ${ }^{\circ} \mathrm{Brix}$ ) using a hand-held refractometer (Atago model Pal 1). The $\mathrm{pH}$ of undiluted juice of each sample was determined using a $\mathrm{pH}$ meter (Micronal model B-474), and titratable acidity (TA) was determined by titration of diluted juice with $0.1 \mathrm{~N} \mathrm{NaOH}$ solution to a phenolphthalein end point and expressed as g. $\mathrm{L}^{-1}$ tartaric acid. An aliquot of the must was freezed in liquid nitrogen and stored at $-20{ }^{\circ} \mathrm{C}$ until analyses of organic acids by HPLC.

A total of 100 berries were analyzed for total phenolics and anthocyanins in a sample. Berries were hand peeled, and the seeds were removed from the pulp, rinsed with distilled water, and blotted dry with paper towels. The skins and seeds were weighted separately, frozen in liquid $\mathrm{N}_{2}$, and stored at $-20{ }^{\circ} \mathrm{C}$ until analyses. The skins were weighed on an analytical balance (Mettler-Toledo AB204), placed in tubes containing $8 \mathrm{~mL}$ of acidified methanol $(1 \% \mathrm{HCl}, \mathrm{v} / \mathrm{v})$, homogenized with an UltraTurrax apparatus (IKA T18 basic) at $14000 \mathrm{rpm}$ for 1 minute, and stored in the dark at $10^{\circ} \mathrm{C}$ for 16 hours. The samples were centrifuged at $7155 \times \mathrm{g}$ for 15 minutes, and the precipitated was washed with acidified methanol untill complete removal of pigments. The supernatant was collected in $50 \mathrm{~mL}$ volumetric

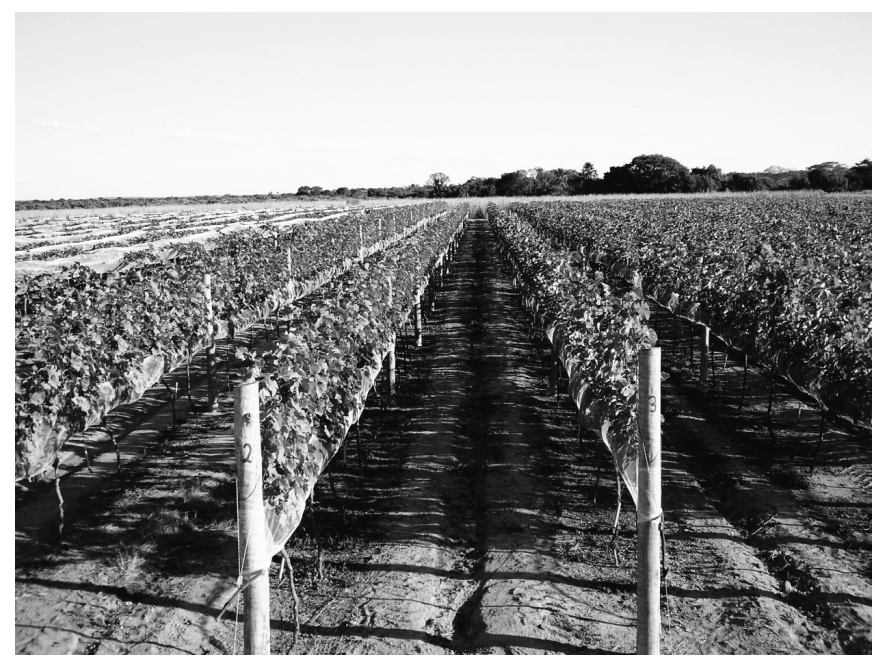

Figure 1. Vines cultivated in Vertical Shoot Position (VSP). João Pinheiro, Minas Gerais, Brazil (winter 2006).

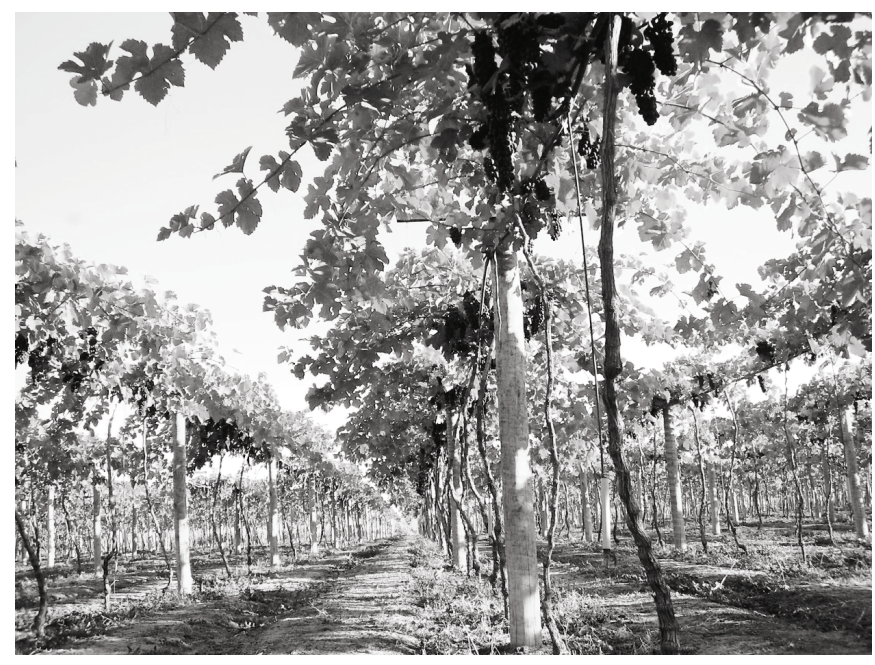

Figure 2. Vines cultivated in Geneva Double Curtain (GDC). João Pinheiro, Minas Gerais, Brazil (winter 2006). 
flasks and used for anthocyanins and total phenolics analyses. Anthocyanins were measured according to Giusti and Wrolstad (2000), and the concentration (expressed as mg pigment $\mathrm{g}^{-1}$ berry skin) was determined using the molecular weight (529) and molar absorbance $(28,000)$ values for malvidin-3glucoside (BERGQVIST; DOKOOZLIAN; EBISUDA, 2001). Total phenolic content of skin was evaluated using the FolinCiocalteu method (AMERINE; OUGH, 1980). The extraction of seed phenolic compounds was done with a solution of acidified methanol ( $\mathrm{HCl} 1 \%)$. The extraction solution volume was proportional to the volume of the berries must, where must volume $=$ berry weight - (seed weight + skin weight $)$.

After storage for 48 hours in the dark, the samples were filtered through glass wool, and total phenolics were measured using the Folin Ciocalteu method. The total phenolic content was expressed as mg gallic acid $\mathrm{g}^{-1}$ of berry skin or seeds.

Analysis of individual organic acids was performed in diluted and filtered must using a Hewlett Packard Series $1100 \mathrm{HPLC}$ system equipped with a Supelcogel C- $610 \mathrm{H}$ $(7.8 \times 300 \mathrm{~mm})$ column $\left(\right.$ at $\left.15^{\circ} \mathrm{C}\right)$ in an isocratic condition and diode array (UV/DAD) detector at $210 \mathrm{~nm}$. Water acidified with fosforic acid solution at $0.5 \%$ was used as a mobile phase at a flow rate of $0.5 \mathrm{~mL} / \mathrm{minute}$.

\subsection{Microvinification}

Harvested bunches were kept at $5{ }^{\circ} \mathrm{C}$ in a refrigerated chamber for 24 hours before vinification.

Grapes were crushed in a stainless steel crusher-destemmer, sulfited with $50 \mathrm{mg} \cdot \mathrm{L}^{-1}$ gaseous $\mathrm{SO}_{2}$, and racked into two $110 \mathrm{~L}$ stainless steel fermentation tanks. Active dry yeasts (Saccharomyces cereviseae) AWRI 796 at 0.2 g.L. ${ }^{-1}$ was inoculated in each tank and kept at $24^{\circ} \mathrm{C}$ controlled temperature. Caps were submerged two times daily by punching down. After 10 days, at the end of alcoholic fermentation, wines without caps were transferred to $13 \mathrm{~L}$ glass recipients (Pyrex ${ }^{\circ}$ ) with Muller type valves, where they completed the malolatic fermentation at $20{ }^{\circ} \mathrm{C}$ followed by paper chromatography. At the completion of malolatic fermentation, all wines were racked, sulfited to $30 \mathrm{mg} . \mathrm{L}^{-1}$ free $\mathrm{SO}_{2}$, and cold stabilized for 15 days at $-3{ }^{\circ} \mathrm{C}$ for tartaric stabilization. After two additional racking in threemonth intervals, wines were bottled and kept in a cave.

\subsection{Wine composition}

Wine density was obtained using a digital densimeter (Gehaka, model DSL-950). Anthocyanins, total phenols, TA, and $\mathrm{pH}$ of the wines were determined as previously described. Alcohol was determined in distilled wine (Gibertini Super DEE) corresponding to distilled wine density at $20{ }^{\circ} \mathrm{C}$ according to AOAC table 913.02 (ASSOCIATION..., 1995). Free and total $\mathrm{SO}_{2}$ were determined using the Ripper method according to Amerine and Ough (1980). Volatile acidity obtained by vapor drag at a Super DEE Gibertini was determined by titration with $0.1 \mathrm{~N} \mathrm{NaOH}$ to a phenolphthalein end point and expressed as g. $\mathrm{L}^{-1}$ acetic acid. Reducing sugars were determined using the Somogy-Nelson colorimetric method at $510 \mathrm{~nm}$ based on a glucose standard curve (NELSON, 1944). Dry extract was determined by the evaporation of wine for 3 hours in an oven at $105{ }^{\circ} \mathrm{C}$ according to the AOAC method 920.62 (ASSOCIATION..., 1995). The ashes were determined by incineration of $5 \mathrm{~mL}$ of wine samples at $550{ }^{\circ} \mathrm{C}$ (AMERINE; OUGH, 1980), and potassium content was determined by flame photometry (Micronal model B262) based on a standard curve according to the AOAC method 965.30 (ASSOCIATION..., 1995). Total polyphenols index was determined at $280 \mathrm{~nm}$ using a spectrophotometer UV/VIS (Quimis model Q-108U), and 420,520, and 620 color indexes were determined using a spectrophotometer at 420,520 and $620 \mathrm{~nm}$, respectively (CURVELO-GARCIA, 1988).

Statistical data analysis was performed by analysis of variance (ANOVA) using the SAEG software. The statistical significant differences were detected applying the Tukey test at $5 \%$ probability.

\section{Results and discussion}

Trellising systems exerted significant influence on soluble sugars, titratable acidity, anthocyanins, and skin total phenolics in Syrah grapes (Table 1).

Total soluble sugars were higher than the average of $19.5^{\circ}$ Brix observed by Silva et al. (2009) in berries of cv. Syrah in mountain vineyards in São Joaquim, SC. At harvest, berries from the GDC system reached values near to $21.5^{\circ} \mathrm{Brix}$, whereas berries from the VSP system showed values around $20.5^{\circ} \mathrm{Brix}$. These values are close to $23^{\circ}$ Brix observed for Syrah berries grown in San Joaquin, California (SANTOS; KAYE, 2009). Most berry sugars loading is derived from leaf photosynthesis (RUFFNER; HÜRLIMANN; SKRIVAN, 1995; DAVIS; ROBINSON, 1996), which is dependent on the total amount of exposed leaf area. Since the trellising system has a dominant influence on the amount of leaf area exposure, the optimal leaf area/crop weight ratio of single- and divided-canopy training systems could explain the results obtained. In the present study, the level of sugars reached by berries from the GDC system was higher than that of berries from the VSP system suggesting that GDC vines were more balanced. Furthermore, divided canopy-training systems such as GDC have considerably higher

Table 1. Effect of training system on the physicochemical composition of Syrah grapevines in João Pinheiro, Minas Gerais, winter 2006.

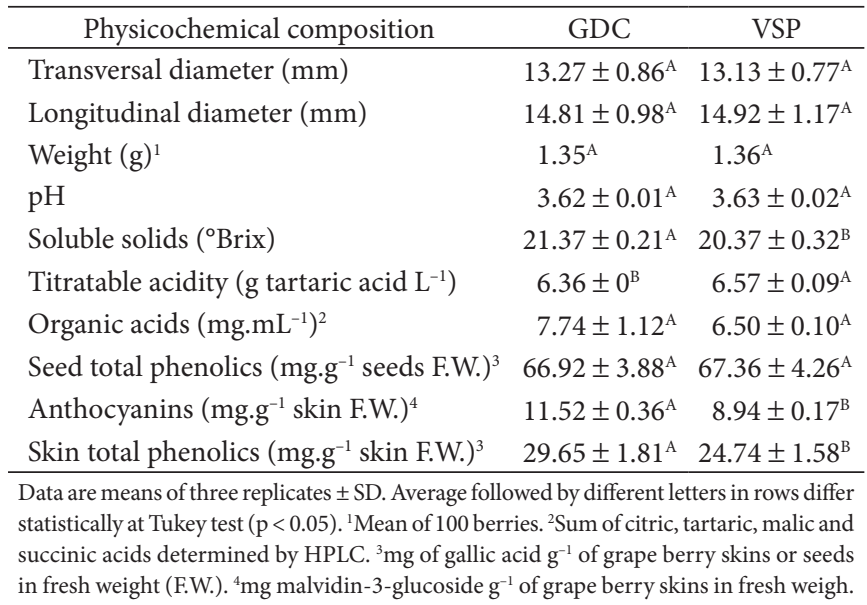


percentage of their leaf area at light saturation compared to that of single canopy-training systems, and therefore a lower leaf area/fruit weight ratio to mature fruit would be expected (KLIEWER; DOKOOZLIAN, 2001).

The average of $6.5 \mathrm{~g} . \mathrm{L}^{-1}$ titratable acidity (Table 1) is close to that observed for cultivar Syrah in 2004 season in San Joaquin, California, 6.3 g.L L $^{-1}$ (SANTOS; KAYE, 2009). Although it was expected to be higher since bunches in vines trained on GDC are protected from direct sunlight, titratable acidity was lower in GDC (Table 1). According to Smart and Robinson (1991), the incidence of sunlight into bunches contributes to organic acids degradation. In fact, although there was no statistical difference in total organic acids between VSP and GDC, citric, tartaric, and malic acid levels were higher in GDC berries (Table 2). In the present study, levels of titratable acidity lower than those of total organic acids in GDC may be explained by the high standard deviation observed for individual acids in GDC must (Table 2), specially citric acid. As organic acids are soluble compounds, precipitation due to storage temperature $\left(-20^{\circ} \mathrm{C}\right)$ is remote. The influence of other compounds on chromatographic peaks seems more likely since organic acids were not purified prior to injection into the chromatographic column.

Berries from the GDC system also showed increased levels of anthocyanins and skin total phenolics. Amounts of 11.52 and $8.94 \mathrm{mg} . \mathrm{g}^{-1}$ of anthocyanins were obtained in berry skins from the vines trained on GDC and VSP, respectively (Table 1). These data are similar or slightly higher than that observed by Silva et al. (2009), 10.08 mg.g ${ }^{-1}$ anthocyanins, in Syrah grape skins in mountain vineyards in São Joaquim.

The incidence of higher anthocyanins and skin total phenolics in GDC may be related to shade incidence into the leaves of the canopy and temperature in the fruitzone (SMART; ROBINSON, 1991; BERGQVIST; DOKOOZLIAN; EBISUDA, 2001; YAMANE et al., 2006). In dense canopies like those of VSP, the amount of sunlight is altered among leaf layers. As sunlight passes through the canopy, there is less sunlight in the visible range relative to the remaining wavelengths of the spectrum. An important consequence is that the ratio of red light $(660 \mathrm{~nm})$ to far red light $(730 \mathrm{~nm})$ declines in the canopy. Plants like grapevines respond to the red:far red ratio via the phytochrome system, which can affect, for example, fruit color development and phenolic compounds accumulation (SMART; ROBINSON, 1991). Another factor that should be taken into

Table 2. Organic acids composition in Syrah grapevines trained on GDC or VSP systems in João Pinheiro, Minas Gerais, winter 2006, determined by HPLC.

\begin{tabular}{ccc}
\hline Organic acid & Trellising & System \\
\hline$\left(\mathrm{mg}^{-1} \mathrm{~mL}^{-1}\right)$ & GDC & VSP \\
\hline Citric & $0.945 \pm 0.577^{\mathrm{A}}$ & $0.462 \pm 0.005^{\mathrm{B}}$ \\
Tartaric & $4.011 \pm 0.374^{\mathrm{A}}$ & $3.538 \pm 0.219^{\mathrm{B}}$ \\
Malic & $2.789 \pm 0.235^{\mathrm{A}}$ & $2.496 \pm 0.122^{\mathrm{B}}$ \\
Succinic & $0.001 \pm 0^{\mathrm{B}}$ & $0.008 \pm 0.006^{\mathrm{A}}$ \\
\hline
\end{tabular}

Values are average \pm SD. Average followed by different letters in rows differ statistically at Tukey test $(\mathrm{p}<0.05)$. account is berry temperature. Bergqvist, Dokoozlian and Ebisuda (2001) showed that anthocyanins increased linearly as sunlight exposure and berry temperature increased to moderate levels, but prolonged exposure of clusters to direct sunlight raised berry temperature to excessive levels and reduced berry color. Yamane et al. (2006) demonstrated that anthocyanin accumulation in the skins was significantly higher at 20 than at $30{ }^{\circ} \mathrm{C}$. Whether temperature or bunch shade is responsible for higher anthocyanin and phenolic compounds in the skins of berries from vines trained on GDC must be evaluated. There was no difference in seed total phenolics between GDC and VSP trellis. Seed total phenolics comprise flavan-3-ol monomers of low molecular weight compounds (catechins and epicatechins) responsible for bitterness in wine and may also have some associated astringency. Longer extraction times, higher temperatures, and higher alcohol concentrations lead to an increase in wine flavan-3-ol monomer concentration in wine (KENNEDY; SAUCIER; GLORIES, 2006).

Although the flavonoid content and composition of a wine reflects the vinification process to some extent, the primarily determinant is the composition of the grapes at harvest. Phenolics accumulated in the grape skin are an important determinant of wine quality. Anthocyanins are phenolic compounds specific to red grape varieties and contribute significantly to the color of wine, whereas tannins are responsible for body, astringency, and complexity of a wine since it combines with anthocyanins contributing to the phenolic stability and playing an important role in wine aging.

Statistical differences of wine composition elaborated from vines trained on VSP and GDC were observed in $\mathrm{pH}$, density, ashes, potassium, total phenolic index, anthocyanins, color intensity, and color shade (Table 3 ). Higher $\mathrm{pH}$ values of wines from VSP grapes may be related to higher potassium and ashes levels found in those samples. Higher anthocyanin content in GDC berries resulted in wines with higher color intensity and higher anthocyanin content per liter of wine when compared to VSP wines.

There are few data on Syrah wine composition in Brazil. Wine composition of Syrah grapes from Pirapora presented higher alcohol content and anthocyanins concentration but lower color intensity and color shade when compared to Syrah wine from grapes harvested in the winter at Três Corações vineyards, in the southern region of Minas Gerais (MOTA et al., 2009). Total phenolic index and color intensity were significantly higher than the average 31.16 and 7.0, respectively, observed by Santos and Kaye (2009) in Syrah wine in California.

The Northeastern region of Minas Gerais state represents a new area for Vitis vinifera grapevine crops based on wine production. In this Cerrado region, characterized by high sunlight intensity and high temperatures, canopy management in GDC training system resulted in better berries ripening and wines with higher color intensity. Whether sun exposure and/or berry temperature were responsible for the observed effects on the composition of Syrah berries and wines in this new growing region must be evaluated in subsequent studies. 
Table 3. Effects of trellising system on wine composition of Syrah grapevines in João Pinheiro, Minas Gerais, winter 2006.

\begin{tabular}{|c|c|c|}
\hline Physicochemical composition & GDC & VSP \\
\hline Total acidity (g tartaric acid L $\left.{ }^{-1}\right)$ & $6.50 \pm 0.09^{\mathrm{A}}$ & $6.50 \pm 0.11^{\mathrm{A}}$ \\
\hline Volatile acidity (g acetic acid L $\mathrm{L}^{-1}$ ) & $0.78 \pm 0.01^{\mathrm{A}}$ & $0.77 \pm 0.01^{\mathrm{A}}$ \\
\hline $\mathrm{pH}$ & $3.67 \pm 0.01^{\mathrm{B}}$ & $3.83 \pm 0.01^{\mathrm{A}}$ \\
\hline Density at $20^{\circ} \mathrm{C}$ & \multicolumn{2}{|c|}{$0.9921 \pm 0.0001^{\mathrm{B}} 0.9932 \pm 0.0002^{\mathrm{A}}$} \\
\hline Alcohol (\% v/v) & $13.52 \pm 0.23^{\mathrm{A}}$ & $13.11 \pm 0.13^{\mathrm{A}}$ \\
\hline Dry extract (g. $\left.\mathrm{L}^{-1}\right)$ & $18.43 \pm 0.44^{\mathrm{A}}$ & $19.02 \pm 1.27^{\mathrm{A}}$ \\
\hline Reducing sugars (g.L $\left.\mathrm{L}^{-1}\right)$ & $0.96 \pm 0.05^{\mathrm{A}}$ & $0.98 \pm 0.02^{\mathrm{A}}$ \\
\hline Ashes $\left(\mathrm{g} \cdot \mathrm{L}^{-1}\right)$ & $2.35 \pm 0.02^{\mathrm{B}}$ & $2.71 \pm 0.03^{\mathrm{A}}$ \\
\hline Potassium (mg. $\left.\mathrm{L}^{-1}\right)$ & $685.17 \pm 18.57^{\mathrm{B}}$ & $814.38 \pm 9.31^{\mathrm{A}}$ \\
\hline Total phenolic index $\left(\mathrm{I}_{280}\right)$ & $54.47 \pm 0.40^{\mathrm{A}}$ & $52.20 \pm 0.26^{\mathrm{B}}$ \\
\hline Total phenolics (g.L $\left.\mathrm{L}^{-1}\right)$ & $2.19 \pm 0.03^{\mathrm{A}}$ & $2.17 \pm 0.03^{\mathrm{A}}$ \\
\hline Anthocyanins (mg.L $\mathrm{L}^{-1}$ ) & $244.68 \pm 5.43^{\mathrm{A}}$ & $232.30 \pm 1.27^{\mathrm{B}}$ \\
\hline Color intensity $\left(\mathrm{DO}_{420}+\mathrm{DO}_{520}+\mathrm{DO}_{620}\right)$ & $12.62 \pm 0.17^{\mathrm{A}}$ & $11.04 \pm 0.05^{\mathrm{B}}$ \\
\hline Color shade $\left(\mathrm{DO}_{420} / \mathrm{DO}_{520}\right)$ & $0.54 \pm 0.01^{\mathrm{B}}$ & $0.63 \pm 0.01^{\mathrm{A}}$ \\
\hline Free $\mathrm{SO}_{2}\left(\mathrm{mg} \cdot \mathrm{L}^{-1}\right)$ & $34.13 \pm 3.69^{\mathrm{A}}$ & $36.27 \pm 3.69^{\mathrm{A}}$ \\
\hline Total $\mathrm{SO}_{2}\left(\mathrm{mg} \cdot \mathrm{L}^{-1}\right)$ & $59.73 \pm 3.69^{\mathrm{A}}$ & $55.47 \pm 3.69^{\mathrm{A}}$ \\
\hline
\end{tabular}

\section{Conclusion}

- 1. GDC trellising system contributed to the increase in total soluble sugars, anthocyanins, and skin total phenolics levels;

- 2. Citric, tartaric, and malic acid levels were lower in the VSP trellising system;

- 3. Total phenolic index, anthocyanins, and color intensity were higher in wines from grapes harvested in vines trained on GDC;

- 4. Canopy management in GDC trellising system results in better berries ripening and wines with higher color intensity in a tropical region of Minas Gerais state.

\section{Acknowledgements}

The authors are grateful for the financial support provided by the foundations "The Minas Gerais State Research Foundation (FAPEMIG) and The National Council for Scientific and Technological Development (CNPq)", Brazil, and the owner of Salvaterra II Farm for providing the grapevines for this study.

\section{References}

AMERINE, M. A.; OUGH, C. S. Methods for analysis of musts and wines. New York: John Wiley \& Sons, 1980. 341 p.

ASSOCIATION OF OFFICIAL ANALYTICAL CHEMISTS - AOAC. Official methods of analysis 16. ed. Washington: AOAC, 1995.

BERGQVIST, J.; DOKOOZLIAN, N.; EBISUDA, N. Sunlight Exposure and Temperature Effects on Berry Growth and Composition of Cabernet Sauvignon and Grenache in the Central San Joaquin Valley of California. American Journal of Enology and Viticulture, v. 52, n. 1, p. 1-7, 2001.
CARBONNEAU, A. Étude écophysiologique des principaux systèmes de conduite - intérêt qualitatif et áconomique de vignes en lyre: premières indications de leur comportement en situation de vigueur élevée. In: CONGRESSO BRASILEIRO DE VITICULTURA E ENOLOGIA, 6., 1990, Bento Gonçalves, Garibaldi. Anais... Bento Gonçalves: EMBRAPA/CNPUV/ ABTEV/OIV, 1991. p. 21-34.

CURVELO-GARCIA, A. S. Controle de qualidade dos vinhos: Química Enológica. Métodos Analíticos. Lisboa: Instituto da Vinha e do Vinho, 1988. 420 p.

DAVIS, C.; ROBINSON, S. P. Sugar accumulation in grape berries. Plant Physiology, v. 111, p. 275-283, 1996.

GIUSTI, M. M.; WROSLTAD, R. E. Characterization and measurement of anthocyanins by uv-visible spectroscopy. New York: John Willey \& Sons, 2000. Current protocols in food analytical chemistry.

GUERRA, C. C. et al. Vinhos tropicais: novo paradigma enológico e mercadológico. Informe Agropecuário, v. 27, n. 234, p. 100104, 2006.

KENNEDY, J. A.; SAUCIER, C.; GLORIES, Y. Grape and wine phenolics: history and perspective. American Journal of Enology and Viticulture, v. 57, n. 3, p. 239-248, 2006.

KLIEWER, W. M.; DOKOOZLIAN, N. K. Leaf area/crop weight ratios of grapevines: influence on fruit composition and wine quality. In: AMERICAN SOCIETY FOR ENOLOGY AND VITICUlTURE, 50., 2001, Seattle. Proceedings... ASEV, 2001. p. 285-295.

MOTA, R. V. et al. Caracterização físico-química e aminas bioativas em vinhos da cv. Syrah. I - Efeito do ciclo de produção. Ciência e Tecnologia de Alimentos, v. 29, n. 2, p. 380-385, 2009. http://dx.doi. org/10.1590/S0101-20612009000200023

NELSON, N. A photometric adaptation of the Somogyi method for the determination of glucose. The Journal of Biological Chemistry, v. 153 , p. $375-380,1944$.

PROTAS, J. F. S.; CAMARGO, U. A.; MELLO, L. M. R. Vitivinicultura brasileira: regiões tradicionais e pólos emergentes. Informe Agropecuário, v. 27, n. 234, p. 7-15, 2006.

REGINA, M. A. et al. Novos pólos vitícolas para produção de vinhos finos em Minas Gerais. Informe Agropecuário, v. 27, n. 234, p. 111-118, 2006.

REYNOLDS, A. G. et al. Impact of training system and vine spacing on vine performance, berry composition, and wine sensory attributes of Seyval and Chancellor. American Journal of Enology and Viticulture, v. 55, n. 1, p. 84-95, 2004.

REYNOLDS, A. G.; WARDLE, D. A.; NAYLOR, A. P. Impact of training system, vine spacing, and basal leaf removal on Riesling. Vine performance, berry composition, canopy microclimate, and vineyard labor requirements. American Journal of Enology and Viticulture, v. 47, n. 1, p. 63-76, 1996.

ROSIER, J. P. Vinhos de altitude: característica e potencial na produção de vinhos finos brasileiros. Informe Agropecuário, v. 27, n. 234, p. 105-110, 2006.

RUFFNER, H. P.; HÜRLIMANN, M.; SKRIVAN, R. Soluble invertase from grape berries: purification, deglycosylation and antibody specificity. Plant Physiology and Biochemistry, v. 33, p. 2531, 1995.

SANTOS, A. O.; KAYE, O. Composição quali-quantitativa da produção de 'Syrah' cultivada sob estresse hídrico transiente. Revista Brasileira de Engenharia Agrícola e Ambiental, v. 13, n. 3, p. 272 281, 2009. http://dx.doi.org/10.1590/S1415-43662009000300008 
SILVA, L. C. et al. Raleio de cachos em vinhedos de altitude e qualidade do vinho da cultivar Syrah. Pesquisa Agropecuária Brasileira, v. 44, n. 2 , p. 148-154, 2009. http://dx.doi.org/10.1590/S0100-204X2009000200006

SMART, R.; ROBINSON, M. Sunlight into wine: A handbook for winegrape canopy management. New Zealand: Ministry of Agriculture and Fisheries, 1991. 88 p.

TODA, F. M. Biologia de la vid: fundamentos biológicos de la viticultura. Madrid: Ed. Mundi-Prensa. 1991. 346 p.
TONIETTO, J.; VIANELLO, R. L.; REGINA, M. A. Caracterização macroclimática e potencial enológico de diferentes regiões com vocação vitícola em Minas Gerais. Informe Agropecuário, v. 27, n. 234, p. 32-55, 2006.

YAMANE, T. et al. Effects of temperature on anthocyanin biosynthesis in grape berry skins. American Journal of Enology and Viticulture, v. 57 , n. 1 , p. $54-59,2006$. 